\title{
PERGEPTION OF THE IMPACT OF NEGATIVE EXTERNALITIES ON THE LOGISTICS DEVELOPMENT OF ADRIATIC SEAPORTS OF KOPER, RIJEKA AND BAR
}

\author{
Mimo Draskovic ${ }^{1^{*}}$ \\ 1) University of Montenegro, Montenegro
}

Please cite this article as:

Draskovic, M., 2019. Perception of the Impact of Negative Externalities on the Logistics Development of Adriatic Seaports of Koper, Rijeka and Bar. Amfiteatru Economic, 21(50), pp. 228-239.

\section{Article History}

Received: 12 Sptember 2018

Revised: 10 November 2018

Accepted: 10 December 2018

DOI: $10.24818 / \mathrm{EA} / 2019 / 50 / 228$

\begin{abstract}
The subject of the paper is to investigate the hypothetical perceptions of the impact of negative externalities on the expansion and development of selected Adriatic seaports. The aim of the paper is to show that Adriatic seaports must accept and apply the integration strategy as a key business and logistic competence, which can be the basis for their expansion and development. Therefore, this paper starts with the basic hypothesis that a partner business performance and cooperation between the Adriatic seaports of Koper, Rijeka, and Bar is a crucial condition for easier finding of large foreign investors and global logistics providers. It also starts with the auxiliary hypothesis that it is necessary to overcome many business barriers, which are treated as negative externalities. For researching the perception of the impact of negative externalities, the multiple linear regression method is used. It is concluded that the level of selected negative externalities is different in individual selected ports, but also between them. The research results verified the initial hypothesis.
\end{abstract}

Keywords: negative externalities, port expansion and logistics development, Adriatic seaports, multiple regression linear approach.

JEL Classification: L92; D62.

\footnotetext{
${ }^{1}$ Corresponding author, Mimo Draskovic-rookie@t-com.me
} 


\section{Introduction}

Seaports are constantly adapting to the changes in the world maritime market in several ways: increasing the size of their infrastructure and suprastructural capacities, technological and information improvement, cooperation with logistics providers and integrating their logistics functions. It is indisputable that investments played a major role in their modernization. Given the long-standing crisis situation, as well as the need to increase business efficiency, the development of logistics services (in terms of marketing logistics and transport logistics in order to achieve a satisfactory degree of integration), outsourcing (Bilan et al., 2017), and regional competitiveness, strategy formulation of Adriatic seaports of Koper, Rijeka, and Bar (the sequence is in terms of development) in the near future should focus on three basic (general) development directions:

- attracting FDI and engaging a well-known global logistics provider as a key and longterm strategic partner,

- building an efficient logistics and information system and outsourcing, and

- wider and greater connection with the hinterland, with the possible organization of free zones and logistics-distribution centers in the wider Montenegrin area.

Bearing in mind the extremely favorable geographic and strategic position of Adriatic seaports, with a high level of safety, it can be assumed that the implementation of the partial business integration strategy will significantly contribute not only to the realization of the aforementioned basic (general) relevant development goals, but also to the following:

- increase the level of quality, the supply universality of their port services and competitiveness in relation to other relatively close seaports (Marlow and Paixao, 2003, p. 195),

- better and advanced logistic and transportation links between the Adriatic seaports, as well as the links with European and world seaports (UNCTAD, 2009; Draskovic, 2013);

- stability and profitability of all their port operations in the long run,

- sustainable development in the considered Adriatic seaports, which implies concern for the natural environment (UN, 2015; Zuzeviciute, et al., 2017; Mikalauskiene, et al., 2018),

- increase the employment and living standards of the population in the wider area, which gravitate towards the mentioned seaports,

- strengthen and improve the overall institutional environment in the countries to which the seaports belong (Delibasic, 2016; Popov, et al., 2016: Yerznkyan, et al., 2017, Draskovic, 2017, Draskovic, et al., 2017), and

- greater overall economic and other benefits for the countries to which the sea ports belong.

It is implied that the realization of the stated goals would not only increase the port traffic, but also a certain redistribution of transport and port services in the region (primarily referring to the considered Adriatic seaports of Rijeka, Koper, and Bar), strengthening their key competences in terms of transport and logistics performance. It is assumed that this would 
overload the freight transport corridors in some parts of Europe. This is particularly relevant for goods of Chinese and Korean origin, hence it would be logical to employ well known global logistics providers as strategic business partners and investors, mostly from China and South Korea.

It has already been conceptually and hypothetically explained (Draskovic, 2013) that realization of the considered idea implies large foreign investments, which should be directed to deepening and leveling the sea gauge (especially in the port of Bar). This would lead to a reduction in and/or significant elimination of the existing feeder service, which significantly increases the total transport of container cargo cost towards the Adriatic seaports, especially the port of Bar, which gets a significant portion of container cargo from the seaports of Rijeka and Koper.

Implementation of this idea also includes a significant degree of partnership cooperation, and the related long-term forms of partial business integration between these ports. It is a necessary condition for overcoming many political, economic, and other problems that objectively exist between the countries belonging to the considered seaports. Achieving such a partnership agreement would enable the synergistic strengthening of the competitiveness and key competencies of all these ports, as well as the consequent increase of their involvement in the global flows of integrated marketing logistics.

\section{Theoretical approach}

Development and implementation of discussed ideas must be seen at the practical regional level (political, economic, and institutional level), with the wider participation and cooperation of all interested regional partners (governmental entities, mentioned Adriatic ports, and the selected global logistics provider). It is also necessary to bear in mind the theoretical model, proposed by A. Montwiłł (2014, p. 260) in accordance with UNCTAD recommendations (2004). It implies the compulsory (minor or greater) integration of particular operating port functions with city and regional functions (i.e. "objective functions" with "spatial functions") in order to build and strengthen logistics centers in the seaport and its hinterland (Figure 1).

This idea could highly correlate with the activation of the wider hinterland of the listed Adriatic seaports (regardless of the existing degree of their infrastructure, logistics, and traffic development). The hinterland of Adriatic seaports can be adjusted to the development of assembly industries and distribution centers for exporting to European countries, banking services and insurance, ecotourism and organic food production for the needs of tourism and export. It also suggests the development of industrial and economic administrations, inspections, quarantines, tax authorities and banks, telecommunications and insurance companies, low taxation and profit repatriation.

The implementation of the partial business integration requires maximal respect for regional, economic, and institutional harmonization, given the specific, complex, crisis and disruptive (mainly inherited) political and economic conditions that still exist to a significant extent in the observed region between the countries in which the said seaports operate. In this respect, we consider that implementation of the discussed idea of expansion, development, and partial business integration of Adriatic seaports and their possible future partnership and cooperation 
requires the elimination of several obstacles that objectively exist. In the past, these obstacles have created a specific braking mechanism, made of several negative externalities, among which the following are the main ones:

- Insufficiently developed mutual political relations between the countries belonging to the selected seaports, and relatively weak consequent regional economic cooperation, with the presence of suspicion and distrust due to unfavorable war events and other political conflicts in the recent past;

- Differences in the institutional development of the countries in which the discussed Adriatic seaports are located (according to the indicators noted by A. Denzau and D. North, 1994; G. Hodgson, 2006; D. Acemoglou and J. Robinson, 2012; B. Yerznkyan, 2012; O. Williamson, 2014; M. Delibasic, 2014, 2016);

- Underdeveloped system of port infrastructure and port superstructure, in accordance with the criteria stated by K. Misztal, 2010; S. Markusik (2009), and A. Grzelakowski and M. Matczak (2012), as well as underdeveloped system of port logistics, in accordance with the criteria stated by UNCTAD (2009), K. Bichou and R. Gray (2004);

- Poor seaport performance indicators, in accordance with the criteria stated by P. Marlow and Paixao (2003), K. Bichou (2006), S. Esmer (2008), M. González and L. Trujillo (2009), P. De Langen and K. Sharypova (2013) and UNCTAD (2016).

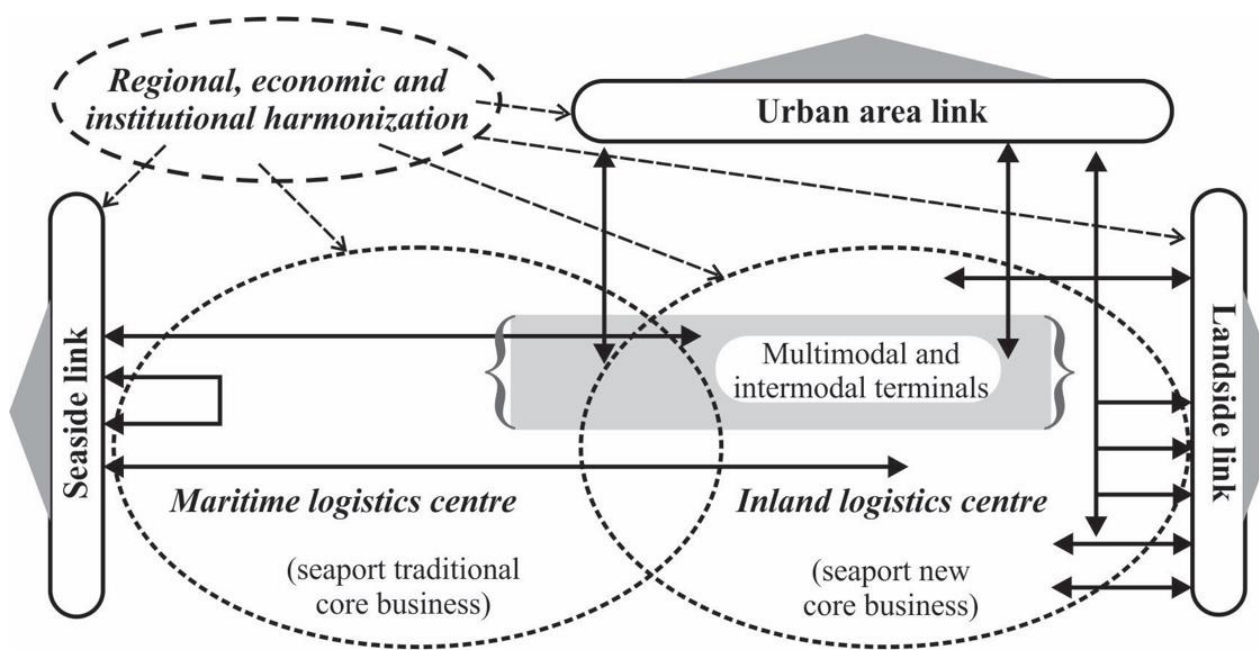

Figure no. 1. Possibilities of logistical and economic development of seaports Source: adapted from UNCTAD, 2004; Montwiłł, 2014.

\section{Adriatic ports case study}

As a methodological framework for the quantitative analysis - a linear multiple regression model was used, with 180 selected citizens surveyed (60 respondents in each country to which a specific seaport belongs - Slovenia, Croatia, and Montenegro). All respondents had 
a high education in the field of economics or logistics, which assumes that their logical thinking was at a high level. In addition, most of them were experts in the port management. They were asked to evaluate, based on their best knowledge, experience and/or intuition, the dependent variable in the model, defined as the degree of economic and logistic development of the selected Adriatic seaports of Koper, Rijeka, and Bar (each respondent for the corresponding seaport in his/her own country).

They were also asked to evaluate the values of three independent variables in the model, defined as the key obstacles (i.e. negative externalities) for the implementation of the considered idea of business cooperation and integration of selected seaports, which related to: a) differences in institutional development of the observed countries, b) underdeveloped system of port infrastructure, port superstructure, and port logistics, and c) poor seaport performance indicators. In all cases, respondents used a scale $(1.0,1.5,2.0,2.5,3.0,3.5,4.0$, $4.5,5.0)$, where 1.0 was the lowest impact, and 5.0 was the highest impact.

Designing the survey and the analysis took into consideration the existing underdeveloped mutual political and economic relations between the countries where the said seaports are located. It is assumed that their improvement is a condition for the future business economic and logistic cooperation.

\section{Multiple linear regression model}

The idea is to create a mathematical model using multiple linear regression analysis, that is, a functional relationship between the dependent variable (Y): level of economic and logistic development of port and independent variables $\left(\mathrm{X}_{1}, \mathrm{X}_{2}\right.$ and $\left.\mathrm{X}_{3}\right)$ : (i) institutional development of port, (ii) port infrastructural, suprastructural and logistic development, and (iii) port performance indicators.

The task is to estimate the expected mean value of the dependent variable $(\bar{Y})$, based on individual estimations of the respondents. Since the respondents have given the estimations based on their own discretion, in line with the requirements of multiple linear regression model, the coefficients $\left(b_{0}, b_{1}, b_{2}, b_{3}\right)$ are to be determined and $\bar{Y}$ calculated by using equation (1):

$\bar{Y}=b_{0}+b_{1} X_{1}+b_{2} X_{2}+b_{3} X_{3} \ldots$

Where:

$\bar{Y}$ - is the mean expected value of the dependent variable;

$b_{0}$ - is $\mathrm{Y}$-axis intercept, determined on the basis of an appropriate sample;

$b_{1}, b_{2}, b_{3}$ - are coefficients of variables $X_{i}, i=\overline{1,3}$, respectively, or slopes of the corresponding lines. 
This practically means that for any new value of each independent variable from a predefined interval, one can estimate the value of the dependent variable. It should be said that $\bar{Y}$ is average estimated value, because it is the mean value of the probability distribution of possible values of Y for given values $X_{i}, i=\overline{1,3}$. To determine $\bar{Y}$ is used the least-squares method (Bertskas, et al., 2008). In fact, our aim here is to determine the coefficients ( $b_{0}, b_{1}, b_{2}, b_{3}$ ), so as to minimize the sum of squared errors (SSE), which is represented by formula (2):

$$
S S E=\sum_{k=1}^{n}\left(Y_{k}-\bar{Y}_{k}\right)^{2}=\sum_{k=1}^{n}\left(Y_{k}-\left(b_{0}+b_{1} X_{1 k}+b_{2} X_{2 k}+b_{3} X_{3 k}\right)\right)^{2} \ldots
$$

Where:

$Y_{k}$ - is actual value of the dependent variable, given by the $\mathrm{k}$ respondents $(k=\overline{1, n})$;

$\bar{Y}_{k}$ - is the estimated value of the dependent variable on the basis of the model, in the case of $\mathrm{k}$ respondents $(k=\overline{1, n})$;

$\mathrm{n}-$ is the total number of respondents (here, per 60 related to the Port of Bar, Port of Rijeka and Port of Koper), $k=\overline{1, n}$.

Using the least-squares method, in the paper is actually determined a straight line, which minimizes the sum of vertical differences for each pair of points (Balakrishnan, et al., 2007). In other words, identified is a straight line that best fits the given set of points, by determining the optimal value of Y-axis intercept $\left(b_{0}\right)$, as well as coefficient $\left(b_{1}, b_{2}, b_{3}\right)$, in order to obtain a more accurate value of $\overline{\mathrm{Y}}$ for the given values of $X_{i}, i=\overline{1,3}$ and $\mathrm{Y}$ (for $\forall k$, $k=\overline{1, n})$.

The realization of multiple linear regression model is very complex, and therefore it is better to leave it to the computer. For this purpose, can be used SPSS (Sheridan and Coakes, 2013; Pallant, 2011), special Excel VBA tools as Excel Modules Solver, which has been used in this analyzes, while other similar tools can be used, as well.

\subsection{Key statistic descriptors}

In addition to the forecasted average value of the dependent variable $\bar{Y}$ and vectors $b_{0}, b_{1}, b_{2}, b_{3}$ ), based on the model applied, the following statistical values can be calculated: mean absolute deviation, mean square error, mean absolute percent error, standard error of regression estimate, correlation coefficient and coefficient of determination. The formulas used to calculate these values are given below, as well as related brief explanations.

Mean absolute deviation (MAD), indicates the numbers on how much the value of the dependent variable, obtained through multiple regression analysis, corresponds to the 
estimated value by the respondents, or in other words, to what extent the model reflects the perception of the respondents (3). Mean square error (MSE) is the mean value of squares of the individual errors of assessment. In other words, if we have n number of respondents, MSE value is calculated using the formula (4). MSE values expressed deviations. Mean absolute percent error (MAPE), indicates the error between the estimated value and value of dependent variable as a percentage, obtained by using the model (5).

The formulas for determining the values of the previously generally described errors in the model are given below:

$$
\begin{aligned}
& M A D=\sum_{k=1}^{n}\left|A_{k}-F_{k}\right| / n \\
& M S E=\sum_{k=1}^{n}\left(A_{k}-F_{k}\right)^{2} / n \\
& M A P E=100 \sum_{k=1}^{n}\left[\left|A_{k}-F_{k}\right| / A_{k}\right] / n
\end{aligned}
$$

Where:

$\mathrm{A}_{\mathrm{k}}$ - is an actual value of a variable (value estimated by respondents), $k=\overline{1, n}$;

$\mathrm{F}_{\mathrm{k}}$ - is an estimated value (by model), $k=\overline{1, n}$;

$\mathrm{n}$ - is a number of respondents (per 60 in the Port of Bar, Port of Rijeka and Port of Koper).

Standard error of the regression estimate (SE), is also called the standard deviation of regression. This statistical value is suitable for the formation of the so-called confidence intervals around the regression line. It indicates how much the value of the dependent variable, obtained by model, can vary numerically (6). Correlation coefficient $-\mathrm{r}$, is used to estimate the strength of linear relationships. Generally, if correlation coefficient is higher than 0.6 , it is considered to be a strong linear relation (7). Coefficient of determination $-\mathrm{r}^{2}$, is a value between 0 and 1, which indicates to what extent (percentage) dependent variable depends on the independent variables included in the model (8).

General formulas for calculating the standard deviation, correlation coefficient and coefficient of determination are given below:

$$
\begin{aligned}
& S E=\sqrt{\sum\left(A_{k}-F_{k}\right)^{2} /(n-2)} \\
& r=\frac{n \sum A_{k} F_{k}-\sum A_{k} \sum F_{k}}{\sqrt{\left[n \sum A_{k}{ }^{2}-\left(\sum A_{k}\right)^{2}\right]\left[n \sum F_{k}{ }^{2}-\left(\sum F_{k}\right)^{2}\right]}}
\end{aligned}
$$


$r^{2}=\left\{\frac{n \sum A_{k} F_{k}-\sum A_{k} \sum F_{k}}{\sqrt{\left[n \sum A_{k}^{2}-\left(\sum A_{k}\right)^{2}\right]\left[n \sum F_{k}{ }^{2}-\left(\sum F_{k}\right)^{2}\right]}}\right\}^{2}$

Where:

$\mathrm{A}_{\mathrm{k}}$ - is an actual value of a variable $(\mathrm{k}=\overline{1, \mathrm{n}})$;

$\mathrm{F}_{\mathrm{k}}$ - is an estimated value $(\mathrm{k}=\overline{1, \mathrm{n}})$;

$\mathrm{n}$ - is a number of respondents (per 60 in the Port of Bar, Port of Rijeka and Port of Koper).

\subsection{Results and discussion}

The respondents, namely per 60 experts for port management in Montenegro (Port of Bar), Croatia (Port of Rijeka) and Slovenia (Port of Koper) were asked to estimate the dependent $(\mathrm{Y})$ and three independent variables in the model $\left(\mathrm{X}_{1}, \mathrm{X}_{2}\right.$ and $\left.\mathrm{X}_{3}\right)$, each with a number on a scale from 0.5 to 5.0. In fact, respondents were supposed to estimate the level of economic and logistic development of port (dependent variable), as well as the extent to which the following independent variables: (i) institutional development of port, (ii) port infrastructure, supra-structure and logistic development, and (iii) port performance indicators - affect the dependent one. Also, the values of statistical parameters, described in the previous section, have been determined in order to analyze the reliability of the proposed predictive model.

Using Excel Modules Solver are obtained the results of multiple regression analysis, for all respondents, for each of the analyzed ports. In fact, determined are coefficients in a function of the dependent variable, that is, the slice on the $\mathrm{Y}$-axis $\left(\mathrm{b}_{0}\right)$ and coefficients $\left(b_{1}, b_{2}, b_{3}\right)$ which correspond to the independent variables, $X_{i}, i=\overline{1,3}$ seriatim. Based on these values and average values, estimated by the respondents, for each of the independent variables, are calculated average values of the dependent variable $\bar{Y}$. These values are shown in Table 1 . Using model are obtained the approximate values: $1.25 ; \mathbf{1 . 5 0}$ and 2.25 , respectively for the case of Port of Bar, Port of Rijeka, and Port of Koper (Table 1). By taking into account that the participants have evaluated the level of economic and logistic development of the analyzed ports by one number on a scale of 0.5 to 5.0 , these are relatively low levels.

Table no. 1. Mean values of the dependent variable $\bar{Y}$ in the case of Port of Bar, Port of Rijeka and Port of Koper

\begin{tabular}{|c|c|c|c|}
\cline { 2 - 4 } \multicolumn{1}{c|}{} & Port of Bar & Port of Rijeka & Port of Koper \\
\hline $\mathrm{b}_{0}$ & 1.302 & 1.789 & 1.393 \\
\hline $\mathrm{b}_{1}$ & -0.030 & -0.079 & 0.005 \\
\hline $\mathrm{b}_{2}$ & -0.064 & -0.098 & 0.166 \\
\hline $\mathrm{b}_{3}$ & 0.007 & 0.028 & 0.159 \\
\hline$\vec{Y}$ & approx. 1.25 & approx. 1.50 & approx. 2.25 \\
\hline
\end{tabular}


Table 2 contains numerical values: mean absolute deviation (MAD), mean square error (MSE), mean absolute percent error (MAPE), standard error of the regression estimate (SE), correlation coefficient ( $r$ ), and coefficient of determination $\left(r^{2}\right)$ for the analyzed sets of respondents' estimations per each of the considered ports.

Table no. 2. Errors, coefficients of correlation and determination

\begin{tabular}{|c|c|c|c|}
\cline { 2 - 4 } \multicolumn{1}{c|}{} & Port of Bar & Port of Rijeka & Port of Koper \\
\hline MAD & 0.383 & 0.326 & 0.315 \\
\hline MSE & 0.198 & 0.162 & 0.152 \\
\hline MAPE & $42.92 \%$ & $23.97 \%$ & $15.00 \%$ \\
\hline SE & 0.461 & 0.417 & 0.404 \\
\hline r & 0.091 & 0.159 & 0.309 \\
\hline$r^{2}$ & 0.008 & 0.025 & 0.095 \\
\hline
\end{tabular}

Following are the graphs (Figures 1-3) showing the actual values of the dependent variable $\mathrm{Y}$, determined on the basis of subjective estimation of $3 \times 60$ respondents - port management experts from Montenegro (Port of Bar), Croatia (Port of Rijeka) and Slovenia (Port of Koper), as well as those calculated by the model, i.e. $\overline{\mathrm{Y}}$.

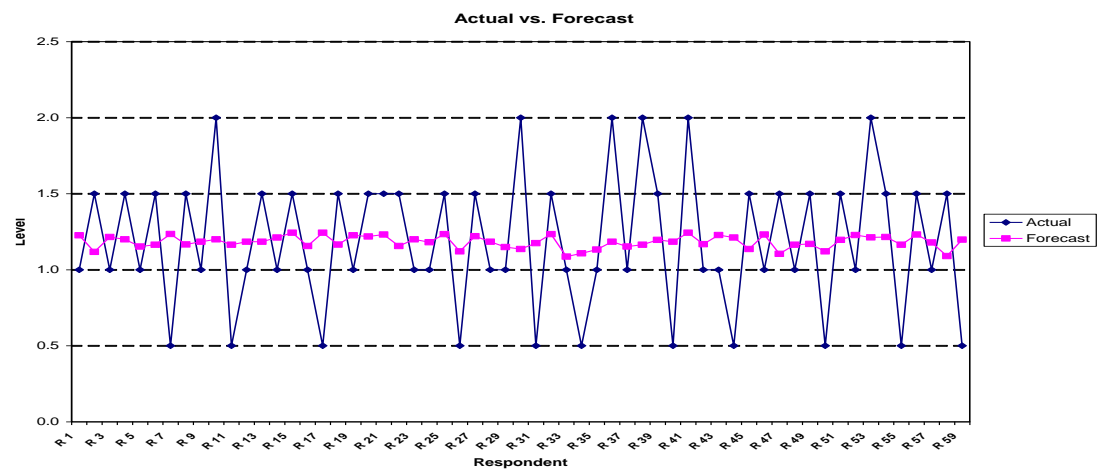

Figure no. 1. The values of the dependent variables, estimated by respondents and those determined by the model, in the case of Port of Bar (Montenegro)

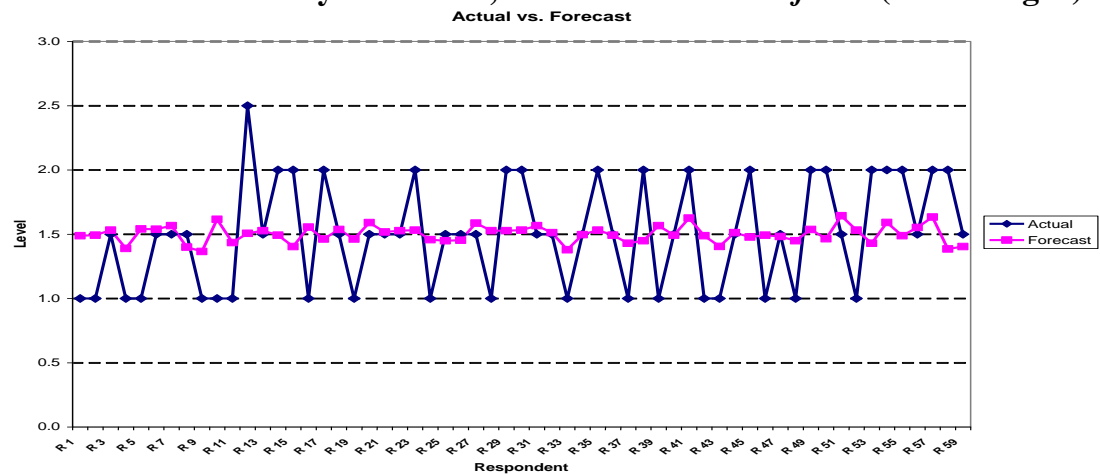

Figure no. 2. The values of the dependent variables, estimated by respondents and those determined by the model, in the case of Port of Rijeka (Croatia) 


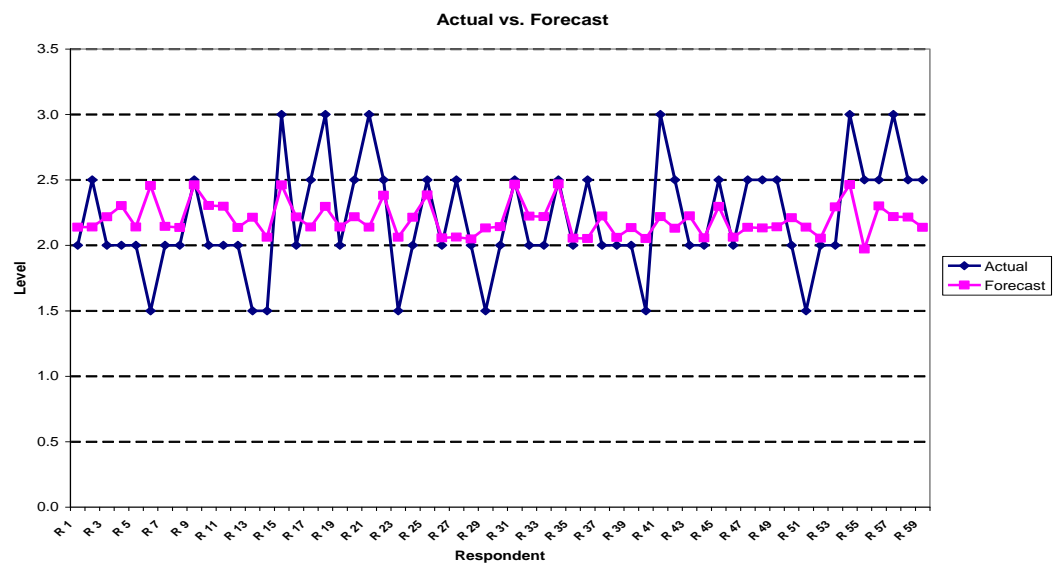

Figure no. 3. The values of the dependent variables, estimated by respondents and those determined by the model, in the case of Port of Koper (Slovenia)

\section{Conclusion}

On the basis of statistical modeling it has been shown that mean expected values of the dependent variable are: 1.25; 1.50; and 2.25 in the cases of Port of Bar (Montenegro), Port of Rijeka (Croatia) and Port of Koper (Slovenia), respectively. Analysis are done over the representative set of input data composed of the truthful responds of a large number of the experts in the field. Linear functional dependence in all three considered case show acceptable level of consistency, with mean absolute percentage errors of: $42 \%$ (Port of Bar); 23\% (Port of Rijeka); and 15\% (Port of Koper).

The proposed regression model can be eventually refined by introducing additional independent variables. Also, lager parent population, or input data set of experts' responds, might be considered in the future research work.

\section{References}

Acemoglou, D. and Robinson, J.A., 2012. Why nations fail: the origins of power, prosperity and poverty. London: Profile Books.

Balakrishnan, N., Render, B. and Stair, R.M., 2007. Managerial Decision Modeling with Spreadsheets. New Jersey: Prentice-Hall Inc.

Bertskas, D.P. and Tsitsiklis, J.N., 2008. Introduction to probability. USA: Athena Scientific.

Coakes, S.J., 2013. SPSS 20.0 for Windows - Analysis without Anguish. Willey Publishing, Inc.

Bilan, Y., et al., 2017. Outsourcing in International Economic Relations. Montenegrin Journal of Economics, 13(3), pp.175-185.

Bichou, K., 2006. Review of port performance approaches and a supply chain framework to port performance benchmarking. Research in Transportation Economics, 17, pp.567-598.

Bichou K. and Gray, R. 2004. A Logistics and Supply Chain Management Approach To Port Performance Measurement. Maritime Political Management, 31(1), pp.47-67. 
Delibasic, M., 2014. The Post-Socialist Transition Through the Prism of O. Williamson's Insight. Montenegrin Journal of Economics, 10(1), pp.13-24.

Delibasic, M., 2016. Hypothetical Matrix for Institutional Modeling of the Basis for Economic Development in the Countries of Southeast Europe. Montenegrin Journal of Economics, 12(2), pp.147-159.

del Saz-Salazar, S. and García-Menéndez, L., 2016. Port Expansion and Negative Externalities: A Willingness to Accept Approach. Maritime Policy \& Management, 43, pp.59-83.

De Langen, P. and Sharypova. K., 2013. Intermodal connectivity as a port performance indicator. Research in Transportation Business and Management, 8, pp.97-102.

Denzau, A.T. and North, D.C., 1994. Shared mental models: ideologies and institutions. Kyklos, 47(1), pp. 3-31.

Draskovic, M., 2013. Organization of Outsourcing in Logistics Partnership Between the Seaports of Montenegro and Slovenia. Montenegrin Journal of Economics, 9(1), pp.93-113.

Draskovic, M., 2017. Possibilities and Limitations of Neo-Institutional Economic Theory in Explaining the Transition Crisis: The Case of Montenegro. Transformations in Business \& Economics, 16(3/42), pp.164-174.

Draskovic, V., Popov, E.K. and Peleckis, K., 2017. Modelling of Institutional Changes in Transition Countries - the Gap Between the Theory and Practice. Montenegrin Journal of Economics, 13(1), pp.125-140.

Esmer, S., 2008. Performance Measurements of Container Terminal Operations. Izmir: Dokuz Eylul University, Institute of Social Sciences.

González, M.M. and Trujillo, L., 2009. Efficiency measurement in the port industry: A survey of the empirical evidence. Journal of Transport Economics and Policy, 43(2), pp.157-192.

Grzelakowski, A. and Matczak, M., 2012. Contemporary sea ports, Gdynia: Gdynia Maritime University (in Poland).

Hodgson, G.M., 2006. Institutions, recessions and recovery in the transitional economies. Journal of Economic Issues, 15(4) USA, pp.875-894.

Markusik, S., 2009. Logistic Infrastructure in Transport, Vol. 1. Means of transport. Gliwice: Silesian University of Technology (in Poland).

Marlow, P.B. and Paixao, C.A., 2003. Measuring Lean Ports Performance. International Journal of transport Management, 1, pp.190-199.

Mikalauskiene, A., et al., 2018. Social Aspect of Sustainable Development: Issues of Poverty and Food Shortage. Montenegrin Journal of Economics, 14(2), pp.59-78.

Misztal, K., ed., 2010. Organization and operation of sea ports. Gdańsk: Gdańsk University (in Poland).

Montwiłl, A., 2014. The role of seaports as logistics centers in the modelling of the sustainable system for distribution of goods in urban areas. Procedia - Social and Behavioral Sciences, 151, pp.257-265.

Pallant, J.F. 2011. SPSS Survival Manual: A Step by Step Guide to Data Analysis Using SPSS. Australia: Allen \& Unwin. 
Popov, E.V., Simonova, V.L. and Kazakova, D.M., 2016. Investigation of Institutional Clustering: Empirical Evidence. Montenegrin Journal of Economics, 12(1), pp.65-74.

$\mathrm{UN}, 2015$. Integrating the three dimensions of sustainable development: A framework and tools. Bangkok, Thailand: ECCAP.

UNCTAD, 2004. Assessment of a seaport land interface: an analytical framework. [pdf] UNCTAD. Available at: <https://unctad.org/en/Docs/sdtetlbmisc20043_en.pdf> [Accessed 20 July 2018].

UNCTAD, 2009. Review of Maritime Transport 2018. [pdf] UNCTAD. Available at: <https://unctad.org/en/PublicationsLibrary/rmt2018_en.pdf> [Accessed 20 July 2018].

UNCTAD, 2016. Port Performance: Linking Performance Indicators to Strategic Objectives. [pdf] UNCTAD. Available at: <https://unctad.org/en/PublicationsLibrary/ dtlkdb2016d1_en.pdf> [Accessed 20 July 2018].

Zuzeviciute, V., Praneviciene, B., Simanaviciene, Z. and Vasiliauskiene, V., 2017. Competence for Sustainability: Prevention of Dis-Balance in Higher Education: The Case of Cooperation While Educating Future Law Enforcement Officers. Montenegrin Journal of Economics, 13(4), pp.121-130.

Williamson, O.E., 2014. The transaction cost economics project. Montenegrin Journal of Economics, 10(1), pp.7-11.

Yerznkyan, B.H., 2012. Pluralistic institutional solutions of the problem of externalities. Montenegrin Journal of Economics, 8(2), pp.73-86.

Yerznkyan, B., Gassner, L. and Kara, A., 2017. Culture, Institutions, and Economic Performance. Montenegrin Journal of Economics, 13(2), pp.71-80. 